Mavi Atlas, 6(1)/2018: 294-307. Araştırma Makalesi | Research Article

Makale Geliş | Received: 31.01 .2018

Makale Kabul | Accepted: 20.03.2018

DOI: 10.18795 /gumusmaviatlas.418993

\title{
Selvihan POLAT
}

Arş. Gör. | Res. Assist. Iğdır Üniversitesi, Fen Edebiyat Fakültesi, Felsefe Bölümü, Iğdır-Türkiye Iğdır University, Faculty of Sciences and Letters, Department of Philosophy, Iğdır-Turkey selvihan.polat@igdir.edu.tr

\section{Negatif Diyalektiğin Kıskacında İyimser Metafiziğin İmkânsızlığı}

\section{$\ddot{O} z$}

$\mathrm{Bu}$ çalışmada 20. yüzyılın en önemli teorisyenlerinden Adorno'nun metafiziğe ilişkin temel saptamalarına yer verilerek, günümüzde metafiziğin imkânı ve içeriği tartışılacaktır. Nitekim günümüz felsefesinde "tarihin sonu"na ve "felsefenin sonu"na vurgu yapan bir tartışma ve bunalım söz konusudur. Böyle bir tartışmada, ahlaki ve insani bir yıkım olarak gördügü Auschwitz deneyiminden yola çıkarak felsefesini oluşturan Adorno'nun metafiziğin içeriğine yönelik tespitleri; oldukça önemli ve açıklayıcıdır. Geleneksel kuramın olumlayıcı niteliğine karşın negatif diyalektik ile olumsuzlamanın imgesi olan Adorno; metafiziği de eleştiri hedefine almaktadır. Metafizik düşünce ile dünyevi deneyim arasındaki parçalanmış uyuma ve hatta karşıtlığa dikkat çekerek bir çatışkıyı yakalamış bulunmaktadır. Bunun yanı sıra Auschwitz'den sonra yaşamın mümkün olup olmadığını sorunsallaştırarak metafizik eleştirisinde de radikal bir duruş sergilemektedir. Metafiziğin iç motiflerinin değiştiğini ve bunun farkına varılmasının gerekliliğini vurgulayarak pozitivistler gibi metafiziğin reddine değil ama radikal bir değişikliğine varmaktadır. Öyle ki, aşkınsal olana vurgu yapan metafizik artık günümüzde maddi gerçekliğe bürünerek dünyevi deneyim ve acı ile uyum içerisinde olmak durumundadır. Diğer bir deyişle olumlu tahayyüller oluşturmak yerine gerçek acıdan yola çıkmak durumundadır.

Anahtar Kelimeler: Adorno, Auschwitz, Dünyevi Deneyim, Metafizik Deneyim, Negatif Diyalektik.

\section{Impossibility of Metaphysical Optimism within the Context of Negative Dialectic}

\begin{abstract}
This study is to discuss the possibility and content of metaphysics today through an examination of the fundamental findings of Adorno, who is one of the most significant theorists of the 20th century. Contemporary philosophy suffers from a depression resulting from discussions on the end of history and the end of philosophy. The findings of Adorno who developed his philosophy about the content of the metaphysics based on the Auschwitz experience which he regarded as an ethical disaster are vital and explanatory. Adorno, who is a symbol of negation through negative dialectic in opposition to the affirmative quality of conventional theory, puts metaphysics among his targets in his criticism. He grasps a conflict through drawing attention to the fragmented harmony and even to antagonism between metaphysical thought and worldly experience. In addition, he adopts a radical attitude in metaphysical criticism through problematizing the question whether life is possible or not after Auschwitz. He arrives not at the denial of metaphysics like other positivists but at a radical change through emphasizing the strong need for an awareness of the varying nature of the internal patterns of metaphysics. Metaphysics, for instance, which formerly pointed out what is transcendental, and which has now transformed into a material reality, has to be in harmony with worldly experience and suffering today. In other words, it has to be based on the real suffering rather than affirmative estimations.
\end{abstract}

Keywords: Phenomenology, Adorno, Auschwitz, Worldly Experience, Metaphysical Experience, Negative Dialectics. 
Hakikatin yalan, yalanın da hakikat gibi göründüğ̈̈ bir dönemeçteyiz şimdi. Adorno

21. yüzyıl felsefede "tarihin sonu"na ve "felsefenin sonu"na işaret eden bir tartışma ve bunalımın yaşandığı bir çağdır. Felsefenin işlevselliği her dönem tartışma konusu olurken özellikle 19. yüzyılın sonu ve 20. yüzyılın başında meydana gelen değişimler ile birlikte - özellikle bilimdeki yükseliş ve bu yükselişin her alana sirayeti felsefenin metafizikten arındırılarak bilimin hizmetine sokulmasına yönelik bir çaba görülmektedir. $\mathrm{Bu}$ doğrultuda bilimdeki gibi bir işlevselliği felsefeye kazandırma amacıyla atılan adımlardan ilki metafiziğin reddedilmesine yöneliktir. Ancak modernitenin hakim olmasıyla modernitenin yol açtığı bunalım metafizik üzerine yapılan tartışmayı alevlendirerek bu tartışmaya başka bir boyut kazandırmaktadır. Bu süreçte artık metafiziğin reddedilmesinden ziyade yeniden metafiziğe dönüş çabas1 görülmekte ve metafiziğin iç motiflerinin değiştirilmesine yönelik bir girişim ve radikal bir eleştiri ortaya çıkmaktadır.

$\mathrm{Bu}$ tartışmayı yoğun olarak felsefesine taşıyan ve Frankfurt Okulu'nun kurucu üyelerinden olan Adorno'nun eleştiriden anladığı şey belli bir konunun tümden reddi ya da olumsuzlanması değil, belirlenimlerin olumsuzlanmasıdır. İnsanı tarihsel nedenler içinde ele alan Adorno, pozitivist kanat gibi metafiziğin felsefeyi işlevsizleştirmesinden dolayı metafiziği reddetme eğiliminde değildir. Bunun yanı sıra Adorno Metafizik Kavram ve Sorunlar'da pozitivistlerin teoloji ile metafizik arasında yaptığı ayrıma teolojik evre, metafizik evre, pozitivist evre - dikkat çekerek metafiziğe teolojiden daha şiddetli eleştiri getirdiklerini belirtmektedir. Metafiziği daha sert eleştirmelerinin nedeni ise pozitif teolojiler tanrısallıklarını olgusal olarak betimlerken, metafiziğin kavramsal olan üzerinde yoğunlaşmasıdır (Adorno 2017: 18,19). Ancak Adorno teoloji ve metafizik arasındaki gerilimi pozitivistler gibi kesip atmamaktadır: "Metafizik ile teolojinin, pozitivistlerin yapmaya uğraştığı gibi tarihsel evreler halinde kolaylıkla ayrılamayacağı besbellidir, zira sürekli tarihsel bakımdan çakışmışlardır: biri ortaya çıktığında öteki de ortaya çıkar; ancak yeniden ön planda ortaya çıkmak üzere unutulmuştur" (Adorno 2017: 20,21). Bunun yanı sıra teoloji ile metafizik arasındaki ortak noktalardan biri mutlak üzerine konuşmalarıdır. Ancak metafizik mutlak üzerine 
konuşurken vahiyden değil de kavramlar üzerinden yola çıkmakta ve bu noktada da teolojinin sert tepkilerine maruz kalmaktadır. Adorno’ya göre teolojinin metafizikten etkilendiği açıktır ve Katolik Kilisesi büyük oranda Aristoteles metafiziğinden beslenmektedir. Adorno metafiziğin Aristoteles ile başladığını ve Batı düşüncesini tamamı ile etkilediğini gerekçeleriyle birlikte açıklamaktadır:

Literatürün gerçekten metafiziksel ilk yapıtında [...] Aristoteles, özü, ondan ayrı ve kesinlikle farklı bir şey gibi, duyular dünyasının karşısına koyan Platoncu girişimi eleştirir. [...] Gelgelim aynı zamanda kendi döneminde zorunlu varlığ 1 duyulur, deneyimlenebilir dünyadan elde etmeye ve böylelikle onu kurtarmaya uğraşır; tam da eleştiri ve kurtarmanın bu çifte amaçlı oluşu, metafiziğin doğasını inşa eden şeydir. Bir yanda eleştirel akılsallık öte yanda kurtarma pathosu, ikisi arasındaki kutuplaşma geleneksel metafiziğin özüne işaret eder. [...] Bunun için metafizik, bir şeyi yıktığ 1 anda o şeyi kurtarmak üzere sarfetme olarak tanımlanabilir (Adorno 2017: 42, Ayrıca bkz. 101,102,147).

Dolayısıyla metafiziğin teoloji ile ilişkisinde; metafizik, bir yandan dogmatik sayılan şeylere eleştirel yaklaşırken diğer yandan bu dogmatik düşünceleri düşünmeye dayalı bir şekilde kavramsal boyutta ele alarak kurtarmaya çalışmaktadır. Adorno metafiziğin özünü oluşturan bu tutumun, eleştirme ve kurtarma pathosunun, Kant’ta da mevcut olduğunu belirtmektedir: "Bu iki yanlılığın, tüm metafiziğin inanca yer açmak için aklı sınırladığını söylediği [...] ünlü cümlesinde tam da bu ikircikliğe işaret eden Kant'ta bile prototipi olduğunu tekrarliyorum" (Adorno 2017: 90). Adorno Ahlak Felsefesinin Sorunları'nda Kant'ın tüm çabasını şöyle özetlemektedir: “Kant felsefesini bir bütün olarak şöyle niteleyebiliriz: Epistemolojik Aydınlanma'yı metafiziği kurtarma, ona göre sadece bilgiye değil fikirlere ve dolayısıyla ahlak yasalarına da ait olan en yüce evrensellerde-tümellerde yoğunlaşmış olan metafizik anlamı yeniden canlandırma girişimiyle birleştiren dağ tüneli” ( Adorno 2012a: 34). Kant; metafiziğgi bilim olarak kurma yoluna girmekte ve metafiziğe yer açma ve metafiziğe işlevsellik kazandırma girişimindedir. Prolegomena'da amacının metafiziğin olanaklı olup olmadığını tartışmaya açarak bir karara varmak olduğunu bildirmektedir: "Ĕger Metafizik bir bilimse, nasıl oluyor da diğer bilimler gibi genel ve sürekli bir tasvip kazanmıyor? Yok, değilse, nasıl oluyor da bilimin kisvesi altında durmadan böbürlenerek insanın anlama yetisini hiç sönmeyen ama hiç de gerçekleşmeyen umutlarla oyalıyor? O halde, [...] bu 
iddialı bilimin yapısı konusunda artık kesin bir karara varmak gerekir" (Kant 2002: 3$4)$.

Metafiziğin tartışmalı pozisyonunu sağlama alma girişiminde Kant'a göre çatışkı diğer bir deyişle antinomi denilen şey ise; aklın sınırlarını aşarak fenomenal alanda kavranamaz olan şeyleri düşünümleme çabasına girerek kendi suçu ile düşmüş olduğu birtakım çözümsüz sorunlardır: "Çatışkı sorunun kaynağı evreni açıklama girişimidir. $\mathrm{Bu}$ girişim insanı ister istemez birtakım çıkmazlara sürükler, gerçekle bağlantısı olamayan sözde çıkarımlarla yüz yüze getirir" (Kant 2004: 15). Aklın kendini alıkoyamadığı birtakım ideler yani ruhun ölümsüzlüğü, özgürlük ve Tanrı'nın varlığı gibi aşkınsal, yanılsamaya neden olan bu ideleri düşünümleme girişimi ile yoldan çıkma eğilimi de "paralojizm" olarak adlandırılmaktadır. Kant'ın fenomenal ve noumenal dünya ayrımı ile Tanrı, ruhun ölümsüzlüğü ve özgürlük gibi metafiziğin konu alanlarını temellendirme girişimi, Adorno'nun genel olarak metafizik eleştirisinden payını almaktadır. Nitekim Adorno'nun metafiziğe ilişkin olumsuzlayıcı tutumunun nedenlerinden biri; metafizik düşüncenin dünyevi deneyimi yansıtmayışı ve metafiziğin olumlayıcı ve iyimser noktasıdır ki bu tutum Aristoteles ile birlikte metafiziğe dahil olmuş bulunmaktadır. Nitekim Aristoteles madde-biçim ayrımı yaparak, biçimin kusursuzluğu ve maddenin kusurlu oluşundan hareketle hareket etmeyen hareket ettiricinin saf biçim ve kusursuz olduğunu öne sürmektedir. Adorno'ya göre burada önemli iki uğrak vardır:

İlkin neredeyse tüm büyük metafizik sistemlerin sahip olduğu olumlayıcı ve iyimser uğrak vardır. Sadece biçimin kusursuz maddenin kusurlu olması yüzünden, maddeye her anlamda gerçekliğin üstünde bir öncelik verilmesi yüzünden gerçekliğin kendisinin, böylelikle, kusursuz değilse bile, en azından kusursuzluğa yönelme eğilimindeki bir şeye dönüştürüldüğünü ileri sürer. [...] $\mathrm{Bu}$ uğraklardan [...] ikincisi, ilk hareket ettiricinin kesinlikle kusursuz olmasının gerekmesi, ontolojik Tanrı kanıtlamasının antik bir öncüsü olması sonucudur. Mutlak kusursuzluk ile mutlak gerçeklik eşitlenmektedir (Adorno 2017: 148,149).

Buradaki olumlu uğrağa Adorno şiddetle karşı çıkmaktadır. Aristoteles'in metafiziğinin olumlu uğrağının yanı sıra can alıcı bir diğer noktası; tümel ile tikel arasındaki ilişkiye vurgu yapmasıdır. Adorno Aristoteles’in, gerçek bir çatışkı olan, 
tümel ile tikel ilişkisini saptamasından dolayı, onun kendinden önceki düşünürlerden olan farkını belirtmektedir. O halde Aristoteles ile başlayan bu problemin metafiziğin başat problemlerinden biri olarak süregeldiği söylenebilmektedir. Ancak, Batı metafiziğginde bu çatışkının saptanması başarısının yanı sıra tümel karşısında tikelin değersizleştirilmesi de söz konusudur. Adorno'nun ifadesiyle, Aristoteles'e göre

Bireyleşimin kendisi tam tamına bu tikelleşme - varolan bir şeyin biçimiyle özdeş olmayışı ya da tam özdeşliği - üzerine kuruludur. Bireyleşim böylece Aristoteles'te olumsuz bir şey haline gelir. Ayrıca bu da, bilişin bir nesnenin genelliği ve zorunluluğu içinde belirlenişiyle bir tutulduğu Kant'ta yeniden ortaya çıktığı haliyle; yalnızca, kendisini bireyleşim aracılı̆̆ıyla ortaya koyan evrenselin tözel olduğu, evrensel ilkeyle özdeşliğin dışında kalan herhangi bir şeyin mutlak biçimde değersiz, fani ve önemsiz görüldüğü Hegel'de en uç noktasına kadar inceden inceye ele alınmış olarak bulduğunuz haliyle tüm Batı metafiziğinin temel bir tezidir (Adorno 2017: 133-134).

Adorno bu noktada açıkça tikel olanın yanındadır. Dolayısıyla Adorno negatif diyalektik ile bütün hiyerarşileri yerinden etmeyi amaçlamaktadır çünkü bu hiyerarşiler olumlama ve uyum üzerine dayalı otoriter veçheye sahip olduğundan tikel olanı yerinden etmektedir.

Adorno bir bütün olarak felsefesinde negatif diyalektik ve içkin eleştiriden hareket etmektedir. $\mathrm{Bu}$ bağlamda Adorno metafiziği de diyalektik olan içinde ele almak gerektiğini belirtmektedir. Çünkü negatif diyalektik metafiziğin olumlayıcı içeriğinin olumsuzlanarak değiştirilmesini mümkün kılmaktadır. Adorno'nun olumsuzluğa vurgusunu Reijen şöyle açıklamaktadır: “Adorno, felsefesini [...] yürürlükteki gerçeklik durumunun 'yanlış’ olduğunu ve değiştirilmesi gerektiğini öneren, evrilen bir olumsuz eleştiri olarak görür” (Reijen 1999: 10). Bu olumsuz eleştiri onun negatif diyalektiğinde belirmektedir. Nitekim bu diyalektik olumsuzlamanın olumlanması şeklindedir ve dolayısıyla Hegel diyalektiğinin yani olumsuzlamanın olumsuzlanmasının tam aksidir, açık uçlu diyalektiktir. Dolayısıyla bir senteze varmayan negatif diyalektik, özgürleşimin ve hakikate varmanın en önemli aracıdır. “Adorno'ya göre hakikate ancak olumsuz anlamda, ona hakkını veremeyen, onu yanlışlayan kavramlar yoluyla ulaşılabilir" (Bewes 2008:19). 
Adorno'ya göre metafiziğin değişmez ve evrensel olana vurgu ile doldurulan içeriği değiştirilerek tikel olan ve dünyevi deneyimle ilişkilendirilmelidir: Diyalektik ele alış 'Platon'dan beri filozofların bıkmadan kınamış oldukları haliyle duyuların sırf bir sureti ya da yanılgısı olarak geçici olan, aşağılık ve değersizdir derken, değişmez olanın doğru ve zorunlu olduğunu varsayamaz. Eğer bize göre, değişmez olanın iyi, doğru ve güzelle denkliğinin basitçe reddedilmiş olduğu bir farkındalıktan başlarsak, o zaman metafiziğin içeriği değiştirilir” (Adorno 2017: 167).

Adorno'nun belirttiği üzere bu nokta metafiziği anlamak ve günümüzde metafizikten bahsedebilmek açısından oldukça önemlidir. Metafizik; artık değişmez olanın üstünlüğünü, değerini vurgulamaktan çekinmelidir. Bugüne kadar düşünce tarihinde metafizik; bütünseli kurma, evrensel olanı yakalama, değişmez olanı vurgulama ve hakikati bunlarla özdeşleştirme çabası içindeydi. Bu bağlamda; ilk felsefe ve hakikat ilişkisini Aristoteles şöyle kurmaktadır: "Felsefeye 'hakikatin bilgisi' denmesi dosdoğrudur. Nitekim temaşa etmeye dayalı <bilimlerin> ereği hakikattir, yapıp-etmeye dair olanlarınkiyse iş/etkinlik; zira yapıp-etmelerle meşgul olanlar bir şeyin nasıl olduğunu araştırsalar bile, ezeli olanı değil, göreli ve şimdi olanı temaşa eder. Ama nedenler olmaksızın hakikati bilemeyiz..." (Aristoteles 2015: 993b 19). Aristoteles bunun yanı sıra bilimler sınıflaması yaparak metafiziği, temaşa etmeye dayalı fizik ve matematikten ele aldığı konu itibariyle ayırarak, "önde gelen" ve "asıl bilim" olarak görmektedir. Bunun nedeni ise asıl bilim dediği metafiziğin bağımsız ve devinimsiz olanı konu edinmesidir. Bu bağlamda; bilimi ilkelere ve nedenlere, bilgeliği ise ilke ve nedenlerin tümel bilgisine sahip olana atfeden Aristoteles "asıl felsefe" olarak adlandırdığı metafiziğin yapısını da şöyle açıklamaktadır: "tümel <olacak> çünkü asıl; ve <bu>, varolan olarak varolanı, hem nesneyi, hem de varolan olmak bakımından <onda> içkin olanları temaşa etme olacaktır" (Aristoteles 2015: 1026a 30). Aristoteles'in bu savlarından da anlaşıldığı üzere metafizik, en soyut ve en tümel kavramların, maddesel olmayan varlığın bilimidir. Dolayısıyla bilge addedilen filozofun da bu varlık alanının tümel bilgisine sahip olması gerekmektedir. Ancak Adorno’ya göre düşünürden beklenen şey, parçalı gerçeklik üzerine yoğunlaşarak kendini bütünsel 
olanın baskısından, evrensel dizgenin yanılsamasından kaçınarak düşünmesidir. Nitekim Adorno Edebiyat Yazıları'nda bu durumu şöyle ifade etmektedir: “Gerçeklik nasıl parçalıysa, o da parçalar halinde düşünür ve kendi birliğini parçaların arasına dalarak bulur, onların üstünü örterek değil. Teksesli bir mantıksal düzen, kavramaya yöneldiği şeyin antagonistik doğası yanıltır bizi” (Adorno 2012b: 30).

Değişmez, evrensel ve bütünsel olana vurgunun önemi; bir yandan bir düşünce alışkanlığı olarak antik çağ filozoflarının Sofistlere karşı kendini savunması ile yoğunlaşırken diğer yandan metafiziğin önemli unsurlarından olan dünyevi alan ile aşkınsal alan arasında yaptığı ayrımdan kaynaklanmaktadır. Adorno bu ayrımın ciddi sorunlar oluşturduğunu belirtmektedir. Aşkınsal alana göre oluşturulan dizgeler gerçeği temsil eden bireyi ve onun içinde yer aldığı maddi varoluşu gözden kaçırmakla birlikte çok ciddi yıkımlara yol açmaktadır. Kant'ın noumenal alana göre tasarlamış olduğu ahlak yasalarının fenomenal alan ile örtüşmemesi ve yol açtığı sorunlar bu bağlamda değerlendirilebilir. Kant'ın ahlak metafiziğinde ahlaki olanın kaynağı; önceki dizgelerde olduğu gibi Tanrı'da, doğada veya toplumsal düzen gibi birtakım dışsal güçlerde değil, içsel bir güç olan akıl idesine dayandırılmaktadır. Dolayısıyla ahlaklılığı aklın özerk yapısında temellendiren Kant olanla değil olması gerekenle ilgilenerek evrensel bir yapı taşıyan ideal düzen tasarımı kurmaktadır. “Adorno’ya göre, evrenselcilik (insanlığın türsel özü olarak), gizli bir biçimde yürürlükteki mevcut hükmetme biçiminde edinilmektedir" (Yibing 2012: 98). Evrensel olanı yakalayabileceğini umarak akla başvuru yapan Kant ahlakının tahakkümcü yapısı yerini Hitler'in ünlü formülüne bırakmıştır: "Aşağıya doğru otorite, yukarıya doğru sorumluluk" (Adorno 2011: 41,42). Bu bağlamda Kant'ın evrensel dizgeleri oluşturabilecek ve bu ilkeleri kabul edecek akla duyduğu güven geç kapitalizmde tamamen örselenmiş durumdadır. Bu örselenme biçimsel açıdan değil içeriksel açıdan gerçekleşmiş görünmektedir ki yasa baskıcı veçhesini ve evrenselliğini korumaya devam ederken içeriksel açıdan daha iyi bir dünya tasavvuruna değil de ahlakiliğin yıkımına ve radikal kötülüğün yayılmasına hizmet eder bir niteliğe bürünmektedir. Dolayısıyla Adorno'ya göre "Bağlı kalınan norm bir kurmacadır; toplumsal önkoşulları da tıpkı örnek aldığı saray seremonisi gibi çoktan 
silinmiştir yeryüzünden: Kabullenilmesinin nedeniyse herhangi bir nesnel ahlaki bağlayıcılık değil, gayri meşru bir çıkar düzeninin meşrulaştırılmasına hizmet etmesidir.” (Adorno 2009: 197). Nitekim Kant'ın içerikten yoksun ama biçimsel anlamda otoriterlerin gözünü kamaştıran ahlak yasası amacından uzaklaştırılarak tahakküm edimlerinin bir aracı haline gelmiş durumdadır. Adorno'nun Minima Moralia' da belirttiği gibi: "Korkulması gereken, insanın lezzetli bir aylaklığa kapılması değil, evrensel doğa maskesi altında toplumsalın vahşice yayılmasıdır: Cinnete dönüşmüş bir faaliyet olarak kolektif” (Adorno 2009: 163,164).

Kant'in ahlak yasasının çokça eleştiriye maruz kalan yönlerinden biri de evrensel ve formalist niteliğinin yanı sıra, fenomenal alanda uygulanabilirliği problemidir. Adorno'nun Negatif Diyalektik’te belirttiği gibi: “Özgürlük kavramı, ampirik gerçekliğe uyarlandığı anda kendine ayak uyduramaz hale gelir. O zaman bizatihi ifade ettiği şey değildir artık" (Adorno 2016: 145). Soyut düzlemdeki ahlak yasası somut duruma uygun değildir. Fenomenal alandan ayrıksı bir şekilde oluşturulan ahlak metafiziği olması gerekene işaret ederken ahlak yasalarının sonuçlarından feragat etmektedir. $\mathrm{Bu}$ noktada Adorno Ahlak Felsefesinin Sorunları'nda kategorik buyruğun formalist yapısının, sadece niyete önem verişi ve eylemlerin sonuçlarını göz ardı edişinin nasıl bir felaket doğurduğuna yönelik Ibsen'in Yaban Ördeği eserini örnek göstermektedir: "Yaban Ördeği bir adamın sırf ahlak yasasını savunmak adına [...] nasıl ahlaksızlaştığı meselesini ele alır. [...] Bu kişi, bütün gruptaki [...] en değerli insanın, olayların akışı içinde tedricen ortaya çıkan suçluluk ağına yakalanmamış tek insanın mahvına yol açar” (Adorno 2012a: 155). Dolayısıyla ahlaki edimlerin sonuçlarından bağımsız olarak ele alınması ve koşulsuz bir "olmalı"dan yola çıkan örselenmiş ve çarpık dünyanın ahlaki pozlar takınan Gregers Werle'leri en masum insanların yok oluşuna neden olmaktadırlar:

Yaralandığından habersiz olan yaralı tarafın onuru için duyulan gereksiz kaygı, her şeyin apaçık olması için gösterilen gereksiz özen, iç temizliğine verilen o abartılı önem -bütün bunlarda daha da sırıtır yalan. Bu değerler çarpık dünyamızın Gregers Werle'leri tarafından öne sürüldüğünde çarpıklık daha da artar. İyi niyetliler, ahlaki soyluluk adına hareket ederken yok edicilere dönüşürler (Adorno 2009: 186). 
Adorno, Lucien Goldmann ile yaptığı konuşmada Yaban Ördeği’nin diyalektik fikrini hayat yalanı ile doğru sözlülük durumu arasındaki gerilimli ilişkiye ve bu ilişkinin en kötü sonucuna dayandırmaktadır.* Dolayısıyla geç kapitalizmde ahlaki antagonizmaların çözümünde akla dayalı ahlak yasası yetersiz kalmaktadır. Dünya o kadar çarpıtılmıştır ki, herhangi bir antagonizma karşısında hangi davranışın doğru veya uygun olacağı hiç de açık değildir. Geç kapitalizm ile birlikte kötülüğün radikalleşmesi söz konusudur. Bu radikal kötülüğün en büyük göstergesi ise ahlaki ve insani bir yıkım olan Auschwitz’tir. Dolayısıyla “Adorno’ya göre [...] burası kötü bir dünya ve insanların bu dünyayı olumlamaması, bu dünyada kendilerini evlerinde gibi hissetmemeleri, kendilerini bu dünyaya yabancı hissetmeleri gerek" (Soykan vd. 2003: 56). İçkin bir şekilde yanlışı ve olumsuzu barındıran koşulların olumlanması kötülüğün rasyonelleşmesine de yol açmaktadır. Öyle ki "Kötülüğün hükümranlığını teslimiyetçi bir tutumla kabullenmenin bizi mecbur bırakabileceği var olan dünyayı olumlama, böylece, bir olasılık belirir gibi olduğu yerde, paramparça edilmiş olmaktadır” (Bloch vd. 2006: 410,411). Mevcut düzenin olumlanması ve dolayısıyla radikal kötülüğün hükmünü devam ettirmesi, bir noktada metafiziğin mevcut düzenden yola çıkmamasından kaynaklanmaktadır. Bu bağlamda, Adorno günümüzde metafizik deneyimin oldukça farklı göründüğünü ve metafizik kavramın değiştirilmesi gerektiğini Auschwitz deneyimi ile açıklamaktadır.

Meydana gelmiş olan şeylere karışmadan, onunla arasına mesafe koyarak ve onu metafiziğin aşağısında bir şey sayarak, her şeyin sırf dünyevi ve insani olması gibi, eski tarz metafizikle uğraşmayı sürdürenler bu yolla kendilerinin insanlık dışı olduğunu kanıtlarlar. [...] O yüzden Auschwitz'den sonra, varlıkta olumlu bir anlam ya da amaç bulunduğunda 1srar etmenin olanaksız olduğunu söyleyeceğim. [...] Aristoteles’te ve ondan önce ilk kez Platon'un öğretisinde bulunan metafiziğin olumlayıcı niteliği olanaksız hale gelmiştir. Varoluşun ya da varlığın kendi içinde oluşturulmuş ve tanrısal ilkeye doğru yönelmiş olumlu bir anlam taşıdığını öne sürmek, filozofların kafadan atmış olduğu tüm doğruluk, güzellik ve iyilik ilkeleri gibi, kurbanların ve onların bitmek bilmeyen işkenceleri karşısında katıksız bir maskaralık olacaktır (Adorno 2017: 168-169).

\footnotetext{
* (Detaylı bilgi için bkz. Theodor Adorno, Lucien Goldmann, Betimleme, Anlama ve Açıklama, Çev. İskender Savaşır, Defter Dergisi, Metis Yayınları, İstanbul 1999, 40., Ayrıca bkz. Adorno, Edebiyat Yazılart, 93,94.)
} 
Adorno metafiziğin varlığın olumlu anlamına ve olumlu ilerleyişine dair vurgusunu bir ad olarak Auschwitz ile değil; işkencenin kurumsallaşmış yapısı olarak gördüğü Auschwitz deneyimi ile değillemektedir. Bu insanlığın imhasını gösteren deneyim, tekrar olma ihtimalini de içinde barındırmaktadır. Diğer bir deyişle, sadece Auschwitz değil şiddetin kalıcı bir kurum haline dönüşmesi, atom bombası, teknoloji destekli soykırım gibi deneyimlerin bir kez gerçekleşmiş olması tekrarını da mümkün kılmaktadır. Dolayısıyla, bu insanlık dışı durumun koşullarını oluşturan ve buna göz yuman bütün düşünce sistemleri bu suçun bir ortağı olarak karşımıza çıkmaktadır. Bu cehennemvari durumların yaşanması üzerine hâlâ olumlayııı bir tutum ile anlam arayışını ahlaksızlık olarak görmektedir.

Adorno Metafizik Kavram ve Sorunlar'da metafiziğin temel konularından olan değişmezliğe vurgu yapan ölümün bile biçim değiştirdiğini ileri sürmektedir: "Gerçek şu ki, ölümün tüm zamanlarda değişmez olduğunu söylemek bir yalandır; ölüm de oldukça soyut bir şeydir; ölümün kendisi çok farklı zamanlarda farklı bir şey olabilir. [...] Artık destansı ya da devasa ölümün olmadığı; hiç kimsenin bitkin, yaşlı ve hayattan doymuş biçimde ölemediği söylenebilir" (Adorno 2017: 176). Yaşamın dayanılmaz ağırlının yanı sıra ölümden başka imgesi olmayan çarpıtılmamış yaşamda ölümü “Auschwitz’ten sonra ölüm” olarak ele almakta ve ölümün korkunç imgesini Negatif Diyalektik’te şöyle ifade etmektedir: “Ölüm toplama kamplarında yepyeni bir dehşete bürünmüştür: Auschwitz’ten bu yana ölümden korkmak, ölümden daha beterinden korkmaktır. Ölümün toplumun mahkûm ettiklerine yaptıkları, sevdiğimiz çok yaşlı insanların biyolojik deneyimlerine bakılarak tahmin edilebilir; sadece bedenleri değil, benlikleri de, onları insan yapan her şey [...] ufalanır” (Adorno 2016: 336).

Ölümün daha da katlanılamaz bir şey olduğunu Metafizik Kavram ve Sorunlar'da ise şöyle açıklamaktadır: "Bugün, bireyin aslında artık varolmayışından ötürü, ölümün büsbütün ölçülemez bir şey haline, bir hiçin yok oluşu haline gelmiş olması muhtemelen doğrudur. Ölen kişi, her şeyden yakayı kurtarmış olduğunu anlar. Ölümün böylesine dayanılmaz oluşunun nedeni de budur" (Adorno 2017: 225). Adorno dünyanın 
gidişatından yola çıkarak, Auschwitz’ten sonra yaşanıp yaşanamayacağını dahi sorgulamaktadır: "İlave bir soru sorulmalıdır; temelleri metafiziğin toptan askıya alınmasında bulunsa da bu, metafizik bir sorudur. Aslında metafiziği olumsuzlayan ve istila eden tüm soruların, tam da böylece tuhaf biçimde nasıl metafizik nitelik edindikleri tuhaftır. Bu, Auschwitz'den sonra yaşanıp yaşanmayacă̆ı sorusudur" (Adorno 2017: 184).

Bunun yanı sıra Adorno'nun dünyanın gidişatını görmezden gelen metafiziği eleştirisinde onun günümüzde felsefenin görevinin ne olduğuna dair ve metafiziğin nasıl olması gerektiğine dair görüşü örtük olarak bulunmaktadır. Şöyle ki:

Bugün eğer metafizik düşünmenin herhangi bir şansı olacaksa ve 'yeni güvenlik' [...] ve benzeri saçma, boş laflarla yozlaşmayacaksa, savunmacı olmayı, savunulacak ve asla kaybedilmeyecek bir şeye işaret etmeyi bırakacak ve kendisine karşı düşünmek zorunda olacaktır. $\mathrm{Bu}$ da, en ufak biçimde bir düşünme hakkına sahip olmak için kendisini nihai, kesinlikle düşünülmez olanın karşısında ölçmesi demektir (Adorno 2017: 190,191).

Burada özdüşünümün önemini vurgulayan Adorno açısından özdüşünüm “...düşüncenin, özellikle bugünlerde hakiki olabilmesi için kendine karşı da düşünmesi gerektiğinin açık bir ifadesidir. Kavramdan kaçan en diştaki unsuru ölçüt bellemeyen düşünce, SS'in kurbanlarının çığlıklarını bastırmak için kullandığı fon müziğiyle aynı kalıptan çıkmadır” (Adorno 2016: 330). Nitekim Adorno’ya göre hakikat özdüşünümde yatmaktadır: "Hakikat [...] hem bilgi içerisinde geleneksel anın devredilemez varoluşunu tanıyan hem de ondaki dogmatik unsuru eleştirel bakımdan tespit eden bir tür öz-düşünümde yatıyor” (Adorno 2017: 230). Metafiziğin düşünülemez olan şeyin üzerine düşünmesi; diğer bir ifadeyle Auschwitz üzerine düşünmesidir. Çünkü Adorno'ya göre Auschwitz “düşünülemez olanın yani tüm bir tarihsel aşamanın ötesindeki düşünülemez olan bir şey anlamına gelir” (Adorno 2017: 191). Bunu da metafiziğin içeriğinin değiştirilmesi olarak gören Adorno, metafiziğin imkânını bu özdüşünüme bağlamaktadır. Dolayısıyla, suçluluk ağına yakalanan ve Auschwitz'in tekrarına neden olabilecek metafizik ancak bu şekilde suçluluk ağından kurtulabilecektir. Adorno Metafizik Kavram ve Sorunlar'da bunun ahlaki veçhesini ise 
negatif kategorik buyruk ile göstererek Kant'1n kategorik buyruğundan farkına dikkat çekmektedir:

Buna, $[. .$.$] ahlâki-felsefi ters bir anlam verebilirim ve diyebilirim ki, Hitler bize$ yeni bir buyruk vermişti: açıkça, Auschwitz'in tekrarlanmaması gerektiği ve onun gibi bir şeyin asla yeniden varolmaması gerektiği. Bu buyruğu mantıkta inşa etmek olanaksızdır; Kantçı buyruğa benzer bir temeli vardır. Kant kendi buyruğunun basitçe verili olduğunu belirttiği zaman, söz konusu iddia kuşkusuz her türden zalimce otoriter ve akıl dışı unsurları taşımakla kalmaz, ayrıca ... doğru eylem alanının sırf akılsallıkla örtüşmediği, bir 'ilave'ye de sahip olduğu farkındalık taşır (Adorno 2017:191).

Pozitif ahlaki buyrukları şiddetle eleştiren Adorno; bu negatif ahlaki buyruğa Negatif Diyalektik'te de yer vermektedir. Bu buyruk; eylemlerin olması gerekene ilişkin değil de mevcut durumdaki ahlaki yıkımın bir daha tekrar etmemesi üzerine kurulan negatif bir buyruktur. Auschwitz'ten sonraki bu negatif buyruk Kant'1n tahakküme yol açan buyruğundan oldukça farklıdır. Kant'ın formalist buyruğunun aksine yeni negatif buyruk oldukça somuttur ve mevcut durumdan hareketle oluşturulmuş bir buyruktur. Dolayısıyla yeni kategorik buyruğun aşkınsal hiçbir temele oturtulmadığı sadece ve sadece tarihsel bir gerçeklik üzerine kurulu olduğu görülmektedir. Nitekim Adorno somutluğun önemini Ahlak Felsefesinin Sorunları'nda şöyle açıklamaktadır: "Bugün ahlak felsefesinin yerinin, insanı varoluşa yerleştirmeye yönelik muğlak ve soyut girişimlerden çok, gayri insani olanın somut olarak ifşa ve itham edilmesinde yattığını söyleyeceğim" (Adorno 2012a: 171). Bu nedenle de Kant'ın buyruğuna yöneltilen eleştiriler yeni kategorik buyruğa yöneltilememektedir. Schweppenhäuser'ın de belirttiği gibi; “Adorno'nun kategorik buyruğu ahlakı tamamıla temellendirebilen bir ilke değildir, aksine o yalnızca örselenmemiş yaşama duyulan saygının minimal ahlakını temellendirir" (Schweppenhäuser 2004: 345).

Kavramın ve anlamın bunalımına dikkat çeken Adorno varoluşa yeniden anlam vermenin olanaksızlığını vurgulayarak metafiziğin maddi varoluşu üzerine geçirmesi gerektiğini belirtmektedir: "Metafizik, [...] maddi varoluşu üstüne geçirivermiştir. Kesinlikle, metafizik sorunların ve metafiziğin kendisinin, [...] maddi katmanına bu geçişi, ne türden olursa olsun resmi evet deyiş tarafından, işbirlikçi bilinç tarafından 
bastırılmış olan şeydir” (Adorno 2017: 193). Metafiziğin dünyanın gidişatından bihaber olmaması gerektiğini düşünen Adorno, yine, ahlak felsefesinin de maddi varoluştan yola çıkmasını önemli bulmaktadır:

Size, ahlâklılığın hakiki temelinin, katlanılmaz acıyla özdeşlik içinde, bedensel duyuda bulunacağını söylersem, çok daha soyut bir biçimde önceden açıklamaya çalıştığım şeyi farklı bir yönden gösteriyor olurum. Açıkça maddeci motifler içinde yaşayan, ahlâk olarak adlandırılabilecek yani doğru yaşama talebi, işte bu ahlâklılıktır. 'Acı vermeyeceksin' buyruğunun metafizik ilkesi - bu buyruk sırf olgusallığın ötesine işaret eden bir metafizik ilkedir - karşı kutba, saf düşünceye değil, ancak maddi gerçekliğe, bedensel, fiziksel gerçekliğe başvurarak kendi gerekçesini bulur (Adorno 2017: 192-193).

Sonuç olarak, metafiziğin Batı düşüncesindeki gelişimi ve sorunlu yanları üzerinde duran Adorno, günümüzde iyiyi işaret eden bir dönüm noktası kalmadığından dolayı metafiziğin olumlu ve iyimser uğrağını eleştirmektedir. Bu ereksel uğrağı, niyete önem veren ve her şeyin çabucak hallolacağını bildiren bir tür burjuva iyimserliği olarak görmektedir. Adorno'ya göre bu olumlu düşünüş, ahlaki ve insani yıkımı ortadan kaldırmak bir yana bu yıkıma yol açan etkenlerden biridir. Hakikatin peşinde olduğunu iddia eden metafizik; Adorno'nun toplumsal gerçeklik olarak nitelediği parçalı hakikati gözden kaçırmaktadır. Toplumsal bir gerçeklik olarak hakikat bir acıdan ibaret olduğundan dolayı mevcut durumdaki parçalanmış hakikati dile getirmek Adorno için, yanlış yaşamda belki de yapılabilecek en ahlaki davranıştır. Metafiziğin bunu dile getirebilmesi için öncelikle maddi gerçekliğe bürünerek dünyevi deneyimden yola çıkması gerekmektedir. 


\section{KAYNAKÇA}

ADORNO, Theodor W. ve Lucien GOLDMANN (1999). "Betimleme, Anlama ve Açıklama", Defter Dergisi, çev. İskender Savaşır, İstanbul: Metis Yayınları.

ADORNO, Theodor W. (2009). Minima Moralia, çev. Orhan Koçak ve Ahmet Doğukan, İstanbul: Metis Yayınları.

ADORNO, Theodor W. (2011). Eleştiri/Toplum Üzerine Yazllar, çev. M. Yılmaz Öner, İstanbul: Belge Yayınları.

ADORNO, Theodor W. (2012a). Ahlak Felsefesinin Sorunlarl, çev. Tuncay Birkan, haz. Thomas Schröder, İstanbul: Metis Yayınları.

ADORNO, Theodor W. (2012b). Edebiyat Yazılarl, çev. Sabir Yücesoy ve Orhan Koçak, İstanbul: Metis Yayınları.

ADORNO, Theodor W. (2016). Negatif Diyalektik, çev. Şeyda Öztürk, İstanbul: Metis Yayınları.

ADORNO, Theodor W. (2017). Metafizik Kavram ve Sorunlar, çev. İsmail Serin, İstanbul: İthaki Yayınları. Yayıncilık.

ARİSTOTELES (2015). Metafizik, çev. Y. Gurur Sev, İstanbul: Pinhan

BEWES, Timothy (2008). Şeyleşme- Geç Kapitalizmde Endişe, çev. Deniz Soysal, İstanbul: Metis Yayıncılık.

BLOCH, E., LUKÁCH, G., BRECHT, B., BENJAMIN, W. \& ADORNO, T. (2006). Estetik ve Politika, çev. Ünsal Oskay, İstanbul: Alkım Yayınevi.

KANT, Immanuel (2002). Gelecekte Bilim Olarak Ortaya Çıkabilecek Her Metafiziğe Prolegomena, çev. İoanna Kuçuradi ve Yusuf Örnek, Ankara: Türkiye Felsefe Kurumu Yayınları.

KANT, Immanuel (2004). Pratik Usun Eleştirisi, çev. İ. Zeki Eyuboğlu, İstanbul: Say Yayınları.

REİJEN, Willem van (1999). Adorno: Bir Giriş, çev. Mustafa Cemal, İstanbul: Belge Yayınları.

SCHWEPPENHAUSER, Gerhard (2004). “Adorno's Negative Moral Philosophy", ed. Tom Huhn, Chambridge Companion to Adorno, Cambridge: Cambridge University Press.

SOYKAN, Ö. N.; KESKIN F. \& B. F. DELLALOĞLU (2003). "Adorno ve Yapıtı", Cogito - Adorno: Kitle, Melankoli ve Felsefe, (Özel Say1), Say1: 36, İstanbul: Yap1 Kredi Yayınları.

YIBING, Zhang (2012). Postmarksist Temel Metinlerin Analizi Cilt I: Adorno'nun Negatif Diyalektiği ve Zizek'in Lacanvari Imkansız Devrimi, çev. Aylin Muhaddisoğlu, ed.Cem Kızılçeç, İstanbul: Kalkedon Yayın Evi. 